\title{
Effects of ectomycorrhizal inoculation and the type of substrate on mycorrhization, growth and nutrition of containerised Pinus pinea L. seedlings produced in a commercial nursery
}

\author{
Ana RINCÓNa*, Javier PARLADÉ ${ }^{\mathrm{b}}$, Joan PERA $^{\mathrm{b}}$ \\ a Departamento de Fisiología y Bioquímica Vegetal, Centro de Ciencias Medioambientales (CCMA-CSIC), C/ Serrano, 115 dupl., 28006 Madrid, Spain \\ b Departament de Protecció Vegetal, Institut de Recerca i Tecnologia Agroalimentaries (IRTA), Centre de Cabrils, Ctra. de Cabrils s/n, \\ 08348 Cabrils (Barcelona), Spain
}

(Received 3 January 2005; accepted 22 August 2005)

\begin{abstract}
Spore inocula of Melanogaster ambiguus (Vittad.) Tul. \& C. Tul., Pisolithus tinctorius (Pers.) Coker \& Couch, Rhizopogon luteolus Fr., Rhizopogon roseolus (Corda) Th. M. Fr. and Scleroderma verrucosum (Bull.) Pers., and two substrates (a mixture of peat-vermiculite and a mixture of peat-composted pine bark) were evaluated for producing mycorrhizal Pinus pinea $\mathrm{L}$. seedlings in a commercial nursery in NE Spain. Inocula of all fungi were effective to obtain containerised mycorrhizal $P$. pinea seedlings although seedling mycorrhization rates were reduced in the peat/pine-bark mixture. Neither inoculation nor the type of substrate modified the first-year growth of seedlings. Rhizopogon spp. increased the levels of $\mathrm{N}$ and $\mathrm{P}$ and, in general inoculation reduced the concentration of $\mathrm{Mn}$ in needles. Symptoms of chlorosis were detected in all seedlings growing in the peat/pine-bark mixture, probably due to nutritional deficiencies caused by the substrate high $\mathrm{pH}$. Among the fungi tested, $R$. roseolus is proposed as the best candidate for its application in nursery inoculation programmes destined to produced containerised mycorrhizal $P$. pinea.
\end{abstract}

Pinus pinea / substrate / mycorrhization / ectomycorrhizal fungi / seedling nursery production

Résumé - Effets d'une inoculation ectomycorhizienne et du type de substrat sur la mycorhization, la croissance et la nutrition de semis de Pinus pinea L. en containers produits en pépinière commerciale. Des inoculums sporaux de Melanogaster ambiguus (Vittad.) Tul. \& C. Tul., Pisolithus tinctorius (Pers.) Coker \& Couch, Rhizopogon luteolus Fr., Rhizopogon roseolus (Corda) Th. M. Fr. et Scleroderma verrucosum (Bull.) Pers., et deux substrats (un mélange de tourbe-vermiculite et un mélange de tourbe-écorce compostée de pin) ont été évalués pour produire des jeunes plants mycorhizés de Pinus pinea L. dans une pépinière commerciale au Nord-Est de l'Espagne. Les inoculums de tous les champignons ont été efficaces pour obtenir des semis mycorhizés de pin pignon en conteneur, bien que les taux de mycorhization ont diminué dans le substrat vermiculite-écorce de pin. Ni l'inoculation ni le type de substrat n'ont modifié la croissance en première année des jeunes plants. Les espèces de Rhizopogon ont augmenté les niveaux d'azote et de phosphore dans les aiguilles des plants et, en général, l'inoculation a réduit la teneur en manganèse de ces feuilles. Des symptômes de chlorose ont été détectés dans tous les plants croissant dans le substrat vermiculiteécorce de pin, probablement en raison des carences nutritionnelles provoquées par le pH élevé du substrat. Parmi les champignons étudiés, on propose $R$. roseolus comme le meilleur candidat pour son application dans des programmes d'inoculation en pépinière destinés à produire des plants de pin pignon mycorhizés en conteneur.

Pinus pinea / substrat / mycorhization / champignons ectomycorhiziens / production des semis en pépinière

\section{INTRODUCTION}

Pinus pinea is a common Mediterranean conifer welladapted to hot and dry conditions associated to this climate. This pine produces edible nuts and plays an important ecological role in arid zones by preventing erosion [25]. These characteristics have increased the value of $P$. pinea in reforestation and afforestation programmes in arid and semiarid regions [25, $26,29]$. Survival and initial growth of out-planted seedlings under these unfavourable environmental conditions is highly dependent on their physiological quality after the nursery breeding period. Different biometrics (height, root collar diameter, shoot-root ratio) and physiological parameters (photosynthetic rates and nutrient accumulation in seedling tissues) have been used as indexes to determine the quality of seedlings produced in nursery $[14,21]$.

Ectomycorrhizal symbiosis with fungi is the rule among most forest tree species in natural conditions [34]. Inoculation

\footnotetext{
* Corresponding author: ana.rincon@ccma.csic.es
} 
with selected ectomycorrhizal fungi has been often signalled as a promising cultural practise for improving the quality of nursery seedling stock [4, 10, 24]. Mycorrhization can improve not only the growth of the seedling but also their physiological status by enhancing the photosynthetic capacity [11] and by increasing the uptake of water and nutrients, and their accumulation in the seedling tissues $[3,8]$.

Environmental conditions marked by the Mediterranean climate are characterised by prolonged dry periods with high temperatures and concentrated rain in a few months. These climatic conditions limit the activity of natural fungal inoculum of soils by reducing the optimal time for fungal spores germination and mycelial growth, thus minimising the opportunities for root colonisation by native fungi $[1,26,27]$. Under these circumstances, controlled nursery inoculation of trees with suitable ectomycorrhizal fungi can be an important advantage for successful establishment of out-planted seedlings in Mediterranean habitats.

Controlled mycorrhization of containerized seedlings is highly dependent on the cultural practices applied in nursery [9]. Generally, factors which affect the growth of seedling roots also affect the development of ectomycorrhizas [24]. Main factors affecting seedling mycorrhization in nursery are the fertilisation and irrigation regimes and the characteristics of the potting substrate $[4,10]$. Aeration, $\mathrm{pH}$ and cation-exchange capacity are important aspects to be considered prior to the election of substrates for seedling production [18]. Composting of residual materials such pine bark is a common recycling practise for obtaining low-cost substrates suitable to produce ornamental and forest seedlings in nurseries $[17,33]$. Nevertheless, the effects of this type of substrates on the mycorrhizal status of forest seedlings produced in nursery are poorly documented.

The objective of this work was to evaluate the effects of inoculation with spores of several ectomycorrhizal fungi using two different substrates (sphagnum peat plus either vermiculite or composted pine bark) on the mycorrhizal status, growth and concentration of nutrients in needles of containerised $P$. pinea seedlings produced in a commercial nursery.

\section{MATERIALS AND METHODS}

\subsection{Plant material}

Pinus pinea $\mathrm{L}$. seeds were collected from natural forests in the Montnegre and Montseny sierras in Catalonia (Spain). Before use, seeds were soaked in running tap water overnight, surface disinfected by shaking for $30 \mathrm{~min}$ in $33 \%(\mathrm{v} / \mathrm{v}) \mathrm{H}_{2} \mathrm{O}_{2}$ and rinsed in four changes of sterile distilled water.

\subsection{Fungal inoculum}

Basidiomata of Pisolithus tinctorius (Pers.) Coker \& Couch., Rhizopogon luteolus Fr., Rhizopogon roseolus (Corda) Th. M. Fr., and Scleroderma verrucosum (Bull.) Pers. were collected in bare-root nurseries and mixed forests of $P$. pinea in different locations of Catalonia (Spain). Sporocarps of Melanogaster ambiguus (Vittad.) Tul \& C. Tul, were collected under Pseudotsuga menziesii (Mirb) Franco plantations in Girona (Spain). After collection, all basidiomata were dried at $35^{\circ} \mathrm{C}$ for $72 \mathrm{~h}$ and kept at room temperature for further use (voucher samples were kept at the herbarium of the DPV-IRTA).
Table I. Analytical characteristics of substrates used to grow Pinus pinea seedlings in the nursery of Breda (Girona, North-Eastern Spain).

\begin{tabular}{lcc}
\hline Substrate parameter & $\begin{array}{c}\text { Peat/Vermiculite } \\
(\mathrm{p} / \mathrm{v})\end{array}$ & $\begin{array}{c}\text { Peat/Composted } \\
\text { pine bark }(\mathrm{p} / \mathrm{pb})\end{array}$ \\
\hline $\mathrm{pH}\left(\mathrm{H}_{2} \mathrm{O} 1: 2.5\right)$ & 5.5 & 7.7 \\
E. C. $(\mathrm{mS} / \mathrm{cm})$ & 2.6 & 2.1 \\
Organic matter $(\%)$ & 44 & 60 \\
Total N (\%) & 0.4 & 0.7 \\
Total P (\%) & 0.3 & 0.3 \\
Total K (\%) & 2.3 & 0.6 \\
Total Mg (\%) & 6.1 & 0.5 \\
Total Fe (\%) & 2.4 & 0.8 \\
Total Mn (ppm) & 185 & 208 \\
\hline
\end{tabular}

To obtain the inoculum of M. ambiguus, R. luteolus and $R$. roseolus, dry mature sporocarps of each fungal species were re-hydrated overnight in distilled water and then blended at low speed until the spores were suspended [5]. For each fungus, initial spore concentration was assessed by using a haematocytometer. The bulk spores suspension was diluted in water to obtain target suspensions of $10^{6}$ spores $\mathrm{mL}^{-1}$ for M. ambiguus, and $2 \times 10^{7}$ spores $\mathrm{mL}^{-1}$ for both Rhizopogon species.

Due to their hydrophobicity, basidiospores of $P$. tinctorius and $S$. verrucosum could not be prepared as water suspensions. Spores of these fungi were removed from the sporocarps by sieving through a $0.5 \mathrm{~mm}$ mesh and counted with a haematocytometer $(0.05 \mathrm{~g}$ spores in $100 \mathrm{~mL} \mathrm{H} \mathrm{H}_{2} \mathrm{O}+$ two drops of Tween 20). One gram of P. tinctorius and $S$. verrucosum spores contained $16 \times 10^{8}$ and $5 \times 10^{8}$ spores respectively.

\subsection{Nursery inoculations and experimental set-up}

Pinus pinea L. seedlings were produced in the commercial nursery owned by Forestal Catalana S.L. in Breda (Girona, Northeastern Spain). A factorial experiment was set up in order to check the effect of the factors: (a) inoculation with spores of the five ectomycorrhizal fungi and (b) type of substrate, on mycorrhization and development of $P$. pinea seedlings. Seedlings were grown in two different substrates commonly used in the nursery: (1) a mixture of peat and vermiculite $(\mathrm{p} / \mathrm{v}) 1: 1(\mathrm{v}: \mathrm{v})$ and (2) a mixture of peat and composted pine bark (p/pb) 1:1 (v:v) (see Tab. I for substrate analyses). The peat Floratorf was purchased at Floragard (Oldenburg, Germany) and the vermiculite Termita ${ }^{\circledR}$, grade 2 at Asflatex S.A. (Barcelona, Spain). Trays with 39 alveoles of $400 \mathrm{~cm}^{3}$ each (Forespot, La Fageda-Spain) were filled with the different substrates, and two $P$. pinea seeds were sowed per alveole. Once germinated, seedlings were thinned to one per container.

Inoculation treatments were performed with spores of the five fungal species plus non-inoculated control plants.

One-month-old seedlings were inoculated with $10 \mathrm{~mL}$ of the target spore suspension of the corresponding fungus. The final inoculum concentration was of $10^{6}$ spores per seedling for M. ambiguus and $10^{7}$ spores per seedling for $R$. luteolus and $R$. roseolus treatments. Dry spores of $P$. tinctorius or $S$. verrucosum were added to a known volume of autoclaved vermiculite before their application. Inoculation with these fungi was carried out by mixing the vermiculite containing the spores with the potting substrate to reach a final concentration of $10^{7}$ spores per seedling in both cases. For all fungi tested, the choice of the spore concentration was based on previous results [32].

Seedlings were fertilised every two weeks with a solution of 20-719 Peters Professional Conifer Grower (Scott, Tarragona, Spain) 
Table II. ANOVA significance levels for the factors inoculation (A) and type of substrate (B), and interaction between them (AB) for different growth parameters of Pinus pinea seedlings. Significant values $(P<0.05)$ are marked in bold.

\begin{tabular}{lccc}
\hline Growth parameter & Inoculation (A) & Substrate (B) & Interaction (AB) \\
\hline Diameter & $\mathbf{0 . 0 0 1}$ & 0.299 & $\mathbf{0 . 0 2 5}$ \\
Height & 0.338 & 0.998 & 0.571 \\
Shoot dry weight (Sdw) & $\mathbf{0 . 0 3 8}$ & 0.292 & 0.409 \\
Root dry weight (Rdw) & $\mathbf{0 . 0 0 0}$ & 0.234 & 0.862 \\
Sdw/Rdw & $\mathbf{0 . 0 0 0}$ & 0.777 & 0.154 \\
\hline
\end{tabular}

$\left(1.8 \mathrm{~g} \mathrm{~L}^{-1}\right)$ and the micronutrients preparation Fetrilon $\left(0.12 \mathrm{~g} \mathrm{~L}^{-1}\right)$ and Hortrilon $\left(0.28 \mathrm{~g} \mathrm{~L}^{-1}\right)$ (Basf, Barcelona, Spain) applied by the nursery irrigation system. The amount of nutrients per plant applied at each fertilisation was: $3.6 \mathrm{mg} \mathrm{N}$ (2.1 nitrate, $1.26 \mathrm{mg}$ ammonia, $0.24 \mathrm{mg}$ urea), $1.26 \mathrm{mg} \mathrm{P}, 3.42 \mathrm{mg} \mathrm{K}, 0.35 \mathrm{mg} \mathrm{Fe}, 0.07 \mathrm{mg} \mathrm{Mg}$, $0.06 \mathrm{mg} \mathrm{Mn}, 0.06 \mathrm{mg} \mathrm{Cu}, 0.01 \mathrm{mg} \mathrm{Zn}, 0.01 \mathrm{mg} \mathrm{B}$ and $0.01 \mathrm{mg}$ Mo.

\subsection{Measured parameters}

Ten months after inoculation, 25 seedlings were randomly harvested in each treatment. Seedling roots were washed free of substrate and ectomycorrhizas were identified according to morphological criteria derived from previous results obtained in synthesis and inoculum dosage trials $[31,32]$. Each seedling root was cut into $2-3 \mathrm{~cm}$ segments, and the percentage of ectomycorrhizal short roots was assessed by counting at least 200 randomly selected short roots under the stereomicroscope.

All seedlings were measured for stem height and root collar diameter. Seedling shoots and roots were oven-dried $\left(60^{\circ} \mathrm{C}, 48 \mathrm{~h}\right)$ to obtain dry weights. Once dehydrated, needles of five plants of the same treatment were grouped as a replicate and ground to a particle size $<2 \mathrm{~mm}$. After digestion of needles by nitric-perchloric acid (5:3), percentages of $\mathrm{N}$ and $\mathrm{P}$ were determined by Kjeldahl and Olsen methods respectively [37]. Concentrations of $\mathrm{K}, \mathrm{Mg}, \mathrm{Mn}$ and Fe were measured by induced plasma spectrophotometry (F586-587, Varian Liberty 220).

\subsection{Statistical analysis}

Data were analysed by two-factor ANOVA and significant differences among treatments were detected by Tukey's test $(P<0.05)$. When factors interacted, they were separately analysed by one-way ANOVA. Percentages of ectomycorrhizas were arc-sin transformed before performing ANOVA.

\section{RESULTS}

\subsection{Mycorrhization}

When grown in $\mathrm{p} / \mathrm{v}$, all seedlings inoculated with $P$. tinctorius, $R$. luteolus, $R$. roseolus and S. verrucosum, and $53 \%$ of those inoculated with $M$. ambiguus became mycorrhizal. When $\mathrm{p} / \mathrm{pb}$ was used, $100 \%$ of seedlings became mycorrhizal with $R$. roseolus whereas this percentage was reduced to $53 \%$ and $33 \%$ in $R$. luteolus and $S$. verrucosum treatments, respectively. In $\mathrm{p} / \mathrm{pb}$, spores inocula of $M$. ambiguus and $P$. tinctorius were not effective and no mycorrhizal seedlings were obtained. Among seedlings growing in $\mathrm{p} / \mathrm{v}$ substrate, the percentages of ectomycorrhizal short roots were of $19 \%$ for M. ambiguus, $45 \%$ for $P$. tinctorius, $57 \%$ for $S$. verrucosum and more than $80 \%$

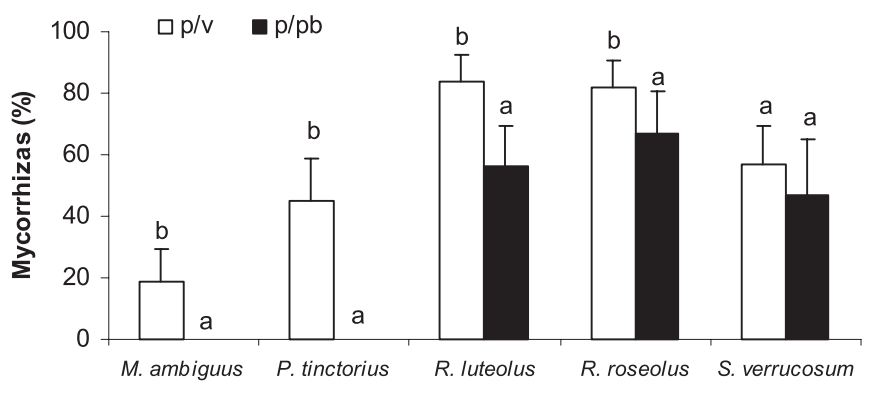

Figure 1. Percentages of ectomycorrhizal short roots obtained by inoculation of Pinus pinea with five ectomycorrhizal fungi, growing in two different substrates. $\mathrm{p} / \mathrm{v}=$ peat $/$ vermiculite $(1: 1, \mathrm{v}: \mathrm{v}) ; \mathrm{p} / \mathrm{pb}=$ peat $/$ pine bark $(1: 1, \mathrm{v}: \mathrm{v})$. In each fungal treatment, different letters denote significant differences between substrates according to Tukey's test $(P<0.05)$.

for both Rhizopogon spp. (Fig. 1). Except for S. verrucosum, the percentage of ectomycorrhizas obtained for all the fungi tested was significantly reduced when seedlings grew in $\mathrm{p} / \mathrm{pb}$ compared with $\mathrm{p} / \mathrm{v}$ substrate (Fig. 1).

\subsection{Seedling growth}

The effects of inoculation on seedling growth were analysed only for $R$. luteolus, $R$. roseolus and $S$. verrucosum. The factor inoculation showed a significant effect on almost all seedling growth parameters, whereas the type of substrate did not significantly influence the growth of seedlings (Tab. II). Inoculation with either fungus generally did not stimulate and even significantly decreased the seedlings growth (Tab. III).

\subsection{Concentration of nutrients in needles}

When the concentration of nutrients in needles was analysed, interaction between inoculation and type of substrate was observed, and statistics were carried out separately for each factor by one-way ANOVA.

In general, inoculation with the different fungi significantly increased the concentration of $\mathrm{N}$ and $\mathrm{P}$ in needles in both substrates, except for plants inoculated with $S$. verrucosum in $\mathrm{p} / \mathrm{v}$ (Fig. 2a). The level of $\mathrm{N}$ in plants inoculated with $R$. roseolus and $S$. verrucosum was significantly higher when grown in $\mathrm{p} / \mathrm{pb}$ substrate compared with $\mathrm{p} / \mathrm{v}$, whereas the concentration of $\mathrm{P}$ in needles was significantly higher when seedling grew in $\mathrm{p} / \mathrm{pb}$ in all inoculation treatments (Figs. 2a and 2b). 
Table III. Growth effect of inoculation with R. luteolus, $R$. roseolus and S. verrucosum on Pinus pinea seedlings. Different letters in each column denote significant differences among treatments according to Tukey' test $(P<0.05)$. Due to interactions, diameter was analysed separately for each factor by one-way ANOVA. Asterisks denote significant differences in diameter between $\mathrm{p} / \mathrm{v}$ and $\mathrm{p} / \mathrm{pb}$ substrates according to Tukey' test $(P<0.05)$.

\begin{tabular}{|c|c|c|c|c|c|c|}
\hline & \multicolumn{2}{|c|}{ Diameter (mm) } & \multirow[t]{2}{*}{ Height $(\mathrm{cm})$} & \multirow[t]{2}{*}{ Shoot dry weight (g) } & \multirow[t]{2}{*}{ Root dry weight (g) } & \multirow[t]{2}{*}{$\mathrm{Sdw} / \mathrm{Rdw}$} \\
\hline & $\mathrm{p} / \mathrm{v}$ & $\mathrm{p} / \mathrm{pb}$ & & & & \\
\hline Control & $3.2 \mathrm{~b}$ & $3.4 \mathrm{~b}$ & $10.6 \mathrm{a}$ & $1.3 \mathrm{~b}$ & $1.0 \mathrm{~b}$ & $1.4 \mathrm{a}$ \\
\hline R. luteolus & $2.6 \mathrm{a}$ & $3.1 \mathrm{ab}^{*}$ & $10.2 \mathrm{a}$ & $1 \mathrm{a}$ & $0.6 \mathrm{a}$ & $1.7 \mathrm{~b}$ \\
\hline$R$. roseolus & $2.9 \mathrm{ab}$ & $2.9 \mathrm{a}$ & $10.6 \mathrm{a}$ & $1 \mathrm{a}$ & $0.6 \mathrm{a}$ & $1.7 \mathrm{~b}$ \\
\hline S. verrucosum & $3.3 \mathrm{~b}$ & $3.0 \mathrm{ab}$ & $9.6 \mathrm{a}$ & $1 \mathrm{a}$ & $0.8 \mathrm{ab}$ & $1.4 \mathrm{a}$ \\
\hline
\end{tabular}
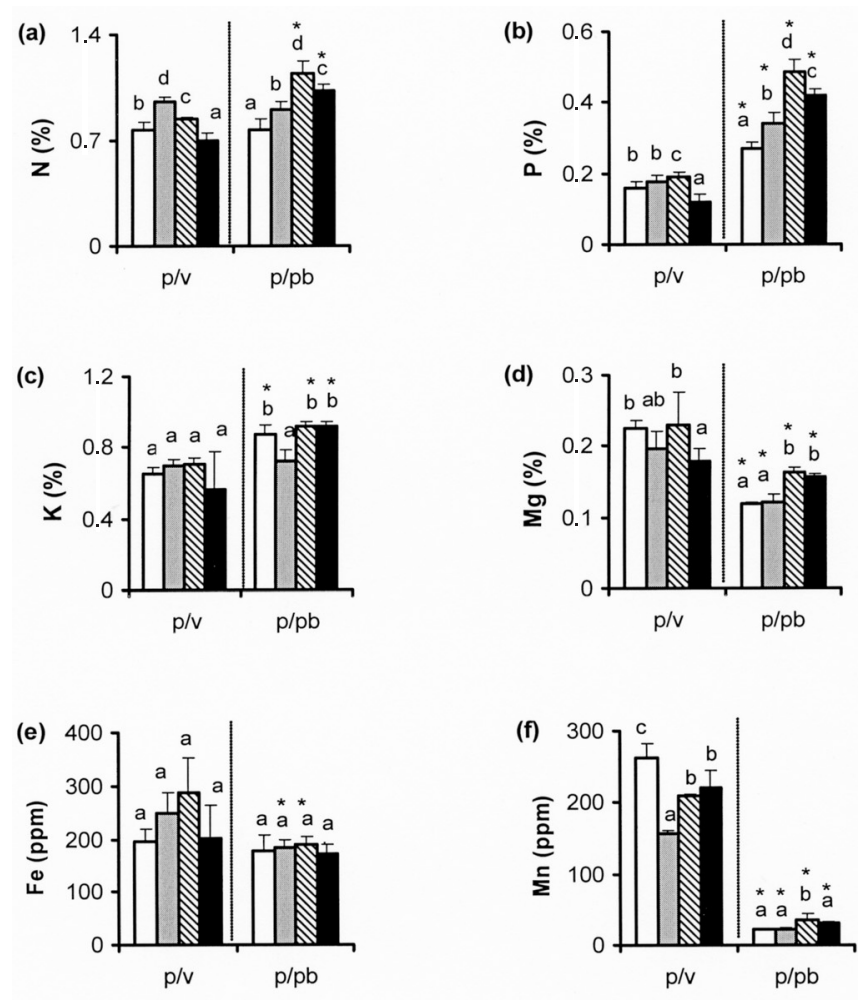

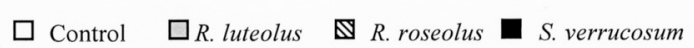

Figure 2. Effect of inoculation and the type of substrate on the concentration of nutrients in needles of containerised $P$. pinea seedlings. $\mathrm{p} / \mathrm{v}=$ peat/vermiculite $(1: 1, \mathrm{v}: \mathrm{v}) ; \mathrm{p} / \mathrm{pb}=$ peat/pine bark $(1: 1, \mathrm{v}: \mathrm{v})$. For each type of substrate, different letters denote significant differences between inoculation treatments according to Tukey's test $(P<0.05)$. For each inoculation treatment, asterisks denote significant differences between $\mathrm{p} / \mathrm{v}$ and $\mathrm{p} / \mathrm{pb}$ substrates according to Tukey's test $(P<0.05)$.

In general, inoculation with the different fungi in the $\mathrm{p} / \mathrm{v}$ substrate did not significantly affect the concentration of $\mathrm{K}, \mathrm{Mg}$ and Fe in needles (Figs. 2c, 2d and 2e). When seedlings grew in $\mathrm{p} / \mathrm{pb}$ substrate, $R$. luteolus significantly reduced the concentration of $\mathrm{K}$ in needles, the level of $\mathrm{Mg}$ in needles was signifi- cantly higher in $R$. roseolus and $S$. verrucosum treatments, and the concentration of Fe was unaffected (Figs. 2c, 2d and 2e). When substrates were compared, the concentration of $\mathrm{K}$ in needles of seedlings was significantly higher in seedlings grown in $\mathrm{p} / \mathrm{pb}$ (except for $R$. luteolus) (Fig. 2b), whereas the concentration of $\mathrm{Mg}$ was significantly reduced (Fig. 2d). Seedlings inoculated with both Rhizopogon spp. showed lower concentration of $\mathrm{Fe}$ in needles when grown in $\mathrm{p} / \mathrm{pb}$ compared with $\mathrm{p} / \mathrm{v}$ substrate (Fig. 2e).

In $\mathrm{p} / \mathrm{v}$, inoculation with the different fungi significantly reduced the concentration of $\mathrm{Mn}$ in needles (Fig. 2f). In p/pb, seedlings inoculated with $R$. roseolus showed the highest levels of $\mathrm{Mn}$ in their needles (Fig. 2f). For all inoculation treatments, the levels of Mn in needles were significantly lower in seedlings grown in $\mathrm{p} / \mathrm{pb}$ than in $\mathrm{p} / \mathrm{v}$ (Fig. 2f).

\section{DISCUSSION}

Spore inoculum of all the fungi tested was effective to obtain mycorrhizal $P$. pinea seedlings produced in container. The high quantity of spores that can be obtained from one basidioma and the ease of application of this type of inoculum makes of it a method particularly well suited for large-scale inoculation of containerised seedlings in commercial nurseries [4, 24]. Low mycorrhization rates were obtained with $M$. ambiguus, with only half of seedlings being mycorrhizal and percentages of ectomycorrhizas (ECM) under $20 \%$. The quantity of spores applied was probably not high enough, since ECM percentages over $80 \%$ have been previously obtained with this fungus for $P$. pinea with application of spore rates over $10^{7}$ spores per seedling [32]. In the case of $P$. tinctorius, even if all plants became mycorrhizal, the percentages of ECM did not reach $50 \%$, the minimal limit established for this fungus to ensure an effect on plant development after transplanting [23, 24]. The minimal level of ECM necessary to ensure seedling performance in the field has been poorly studied, and probably depends on environmental characteristics of the site of transplantation and on the fungus-tree combination used [4, 34]. The spore inoculum of $P$. tinctorius has been successfully used in previous experiments to produce containerised Pinus species, including $P$. pinea $[15,28,32]$.

The highest mycorrhization rates of $P$. pinea seedlings were obtained with spores of $R$. luteolus and $R$. roseolus. Species of the genus Rhizopogon have been previously used in nursery 
programmes for the production of mycorrhizal $P$. pinea seedlings with similar results [27, 29, 32].

Both, the percentages of mycorrhizal seedlings and the colonisation level obtained with all the fungi tested in this study, except with $S$. verrucosum, were significantly reduced when seedlings were grown in the substrate containing peat and composted pine bark (p/pb). For M. ambiguus and $P$. tinctorius, composted pine-bark even totally prevented the formation of mycorrhizas. The relatively high $\mathrm{pH}$ value (7.7) of the substrate could have reduced the efficacy of all fungi tested. Since most of them are acidophilous, both the germination of fungal spores and the development of mycorrhizas can be severely affected by $\mathrm{pH}$ values over $6[9,19]$. Interestingly in $\mathrm{p} / \mathrm{pb}$ substrate, $R$. roseolus was the only fungus which colonised all seedlings, forming ECM in percentages close to $70 \%$. These results indicate that inoculation with $R$. roseolus spores and the use of alternative less-expensive and recycled substrates are compatible nursery practises for the production of mycorrhizal $P$. pinea seedlings in container.

Inoculation with the different fungi generally did not stimulate and even reduced seedlings growth. Low growth rates in mycorrhizal plants have been often attributed to the high demand for carbohydrates required by the fungus $[11,35]$. The lack of stimulation of seedlings growth by the fungi could also be influenced by nursery practices like the fertilisation levels, the type of substrate, or the container size [9]. When growing in the soil, $R$. luteolus, $R$. roseolus and $S$. verrucosum produce abundant external mycelium and rhizomorphs, which are of great importance for water and nutrient uptake under field conditions [7, 34]. However, the benefices of these fungal structures could be minimised under nursery conditions.

On the other hand, the type of potting substrate did not affect $P$. pinea seedlings growth. Composted pine-bark is a substrate commonly used in Spanish nurseries, and it has been previously tested for the production of containerised $P$. pinea seedlings with growth standards acceptable for its commercialisation [17].

Mycorrhization with the different fungi tested in this study directly affected the nutritional status of $P$. pinea seedlings, and therefore their physiological quality. Inoculation of $P$. pinea with $R$. luteolus and $R$. roseolus increased the concentration of $\mathrm{N}$ and $\mathrm{P}$ in needles. Some authors have demonstrated an improved $\mathrm{N}$ and $\mathrm{P}$ uptake by mycorrhizal roots compared with non-mycorrhizal ones [3, 13], although controversial results have also been reported [11]. Inoculation with $S$. verrucosum reduced the concentration of $\mathrm{N}, \mathrm{P}, \mathrm{Mg}$ and $\mathrm{Mn}$ in needles when seedlings were grown in peat-vermiculite substrate, whereas this effect was reversed in peat-pine bark substrate. These results support the importance of the characteristics of the potting substrate affecting the availability of nutrients for the fungus and its positive or negative effect on seedlings nutrition. Also, other seedling parts such stem and roots as well as the mantle and the external mycelium produced by the fungus may act as nutrient storage structures and should be taken into account in a global nutrient balance [7].

A common feature found for all fungi studied was that inoculation significantly reduced the levels of $\mathrm{Mn}$ in $P$. pinea needles from plants growing in the $\mathrm{p} / \mathrm{v}$ substrate. Different authors $[2,20]$ have demonstrated a lower Mn uptake in plants mycorrhizal with arbuscular fungi compared with non-mycorrhizal ones. The availability of Mn for the plants is dependent on oxidation/reduction processes often driven by soil microorganisms capable to reduce Mn [22]. Some authors have suggested that mycorrhization can inhibit the proliferation of such microorganisms in the rhizosphere by modifying the composition of root exudates [16, 30].

Symptoms of chlorosis were detected in all seedlings growing in $\mathrm{p} / \mathrm{pb}$ substrate, probably due to deficiencies in Fe, $\mathrm{Mg}$ or $\mathrm{Mn}$ [21]. High $\mathrm{pH}$ values in the $\mathrm{p} / \mathrm{pb}$ substrate could affect the availability of nutrients to the plant and their accumulation in needles $[21,22,36]$. At high $\mathrm{pH}$ levels, metallic micro-nutrients such $\mathrm{Fe}, \mathrm{Mn}, \mathrm{Cu}$ and $\mathrm{Zn}$ are converted to insoluble oxides and hydroxides not available for the plants [36]. For this reason, many conifers tend to show chlorosis symptoms when grown in alkali soils, and different authors recommend a $\mathrm{pH}$ of 5-6 for their production [36]. The quality of a substrate for conifer production is directly related with its water retention capacity and the porosity [18], and usually a mixture of equal parts of sphagnum peat and vermiculite is recommended as potting substrate for the production of mycorrhizal seedlings [4]. The vermiculite ameliorates the aeration properties of the substrate and it has certain cation-exchange capacity which means higher availability of nutrients like $\mathrm{Mg}$ and $\mathrm{K}$ for the plant [18]. In the peat/composted pine bark substrate, the mixture of two organic components gives a high $\mathrm{C}: \mathrm{N}$ relation and this could be the cause for the immobilisation of certain nutrients [4]. Ideally, composted pine bark should be mixed with an inert substrate such vermiculite, sand or perlite for a better aeration, fixing $\mathrm{pH}$ levels not higher than 6 for the production of conifer seedlings. Nevertheless, Mediterranean pines like $P$. pinea and $P$. halepensis can properly grow in soils with neutral and even basic $\mathrm{pH}$ [29].

Among all fungi tested in this study, $R$. roseolus has demonstrated the highest infectivity of $P$. pinea seedlings even in a substrate with high $\mathrm{pH}$ levels. Several species of the genus Rhizopogon have been successfully used for controlled mycorrhization of different conifers in nursery [5, 6, 12]. Moreover, the efficacy of $R$. roseolus in field trials for $P$. pinea establishment has been demonstrated [29]. Rhizopogon roseolus can be considered as a good candidate for its application in nursery inoculation programmes destined to produce containerised mycorrhizal $P$. pinea seedlings.

Acknowledgements: This work was supported by the European Commission Contract AIR2-CT94-1149. The first author was granted (94/ 97 FPI programme) by the Ministerio de Educación y Ciencia, Spain.

\section{REFERENCES}

[1] Argillier C., Falconnet G., Tillard P., Mousain D., Essais d'introduction dans un arénosol calcaire de Petite-Camargue de pins pignons (Pinus pinea L.) mycorhizés par Suillus collinitus, Rev. For. Fr. XLIX (1997) 131-140.

[2] Arines J., Porto M.E., Vilariño A., Effect of manganese on vesicular-arbuscular mycorrhizal development in red clover plants and on soil Mn-oxidizing bacteria, Mycorrhiza 1 (1992) 127-131.

[3] Boxman A.W., Roelofs J.G.M., Some effects of nitrate versus ammonium nutrition on the fluxes of Pinus sylvestris seedlings. Effects of mycorrhizal infection, Can. J. Bot. 66 (1988) 1091-1097. 
[4] Brundrett M., Bougher N., Dell B., Grove T., Malajczuk N., Working with mycorrhizas in forestry and agriculture, ACIAR Monograph 32, Camberra, Australia, 1996.

[5] Castellano M.A., Trappe J.M., Molina R., Inoculation of containergrown Douglas-fir seedlings with basidiospores of Rhizopogon vinicolor and $R$. colossus: effects of fertility and spore application rate, Can. J. For. Res. 15 (1985) 10-13.

[6] Chu-Chou M., Grace L.J., Comparative efficiency of the mycorrhizal fungi Laccaria laccata, Hebeloma crustuliniforme and Rhizopogon species on growth of radiata pine seedlings, N. Z. J. Bot. 23 (1985) 417-424.

[7] Colpaert J.V., Van Laere A., Van Assche J.A., Carbon and nitrogen allocation in ectomycorrhizal and non mycorrhizal Pinus sylvestris L. seedlings, Tree Physiol. 16 (1996) 787-793.

[8] Conjeaud C., Scheromm P., Mousain D., Effects of phosphorous and ectomycorrhiza on maritime pine seedlings (Pinus pinaster), New Phytol. 133 (1996) 345-351.

[9] Cordell C.E., Marx D.H., Effects of nursery cultural practises on management of specific ectomycorrhizae on bare-root tree seedlings, in: Pfleger F.L., Linderman R.G. (Eds.), Mycorrhizae and Plant Health, APS Press, St. Paul, Minnesota, 1994, pp. 133-151.

[10] Cordell C.E., Owen J.H., Marx D.H., Mycorrhizae nursery management for improved seedling quality and field performance. Meeting the challenge of the nineties, Proc. Intermount. For. Nursery Assoc. Oklahoma City, Okla, GTR-RM-151, 1987, pp. 105-115.

[11] Dosskey M.G., Boersma L., Linderman R.G., Role for the photosynthate demand of ectomycorrhizas in response of Douglas-fir seedlings to drying soil, New Phytol. 117 (1991) 327-334.

[12] Duñabeitia M.K., Hormilla S., García-Plazaola J.I., Txarterina K., Arteche U., Becerril J.M., Differential responses of three fungal species to environmental factors and their role in the mycorrhization of Pinus radiata D. Don, Mycorrhiza 14 (2004) 11-18.

[13] Eltrop L., Marchner H., Growth and mineral nutrition of nonmycorrhizal and mycorrhizal Norway spruce (Picea abies) seedlings grown in semi-hydroponic sand culture. I. Growth and mineral nutrient uptake in plants supplied with different forms of nitrogen, New Phytol. 133 (1996) 469-478.

[14] Fernández M., Royo A., Gil L., Pardos J.A., Effects of temperature on growth and stress hardening development of phytotron-grown seedlings of Aleppo pine (Pinus halepensis Mill.), Ann. For. Sci. 60 (2003) 277-284.

[15] González-Ochoa A.I., de las Heras H., Torres P., Sánchez-Gómez, E., Mycorrhization of Pinus halepensis Mill. and Pinus pinaster Aiton seedlings in two commercial nurseries, Ann. For. Sci. 60 (2003) 43-48.

[16] Grayston S.J., Vaughan D., Jones D., Rhizosphere carbon flow in trees, in comparison with annual plants: the importance of root exudation and its impact on microbial activity and nutrient availability, Appl. Soil Ecol. 5 (1996) 29-56.

[17] Guerrero F., Gascó J.M., Hernández-Apaolaza L., Use of pine bark and sewage sludge compost as components of substrates for Pinus pinea and Cupressus arizonica production, J. Plant Nutr. 25 (2002) 129-141.

[18] Heiskanen J., Favourable water and aeration conditions for growth media used in containerised tree seedling production - a review, Scand. J. For. Res. 8 (1993) 337-358.

[19] Hung L.-L.L., Trappe J.M., Growth variation between and within species of ectomycorrhizal fungi in response to $\mathrm{pH}$ in vitro, Mycologia 75 (1983) 234-241.
[20] Kothari S.K., Marschner H., Römheld V., Effect of a vesiculararbuscular mycorrhizal fungus and rhizosphere microorganisms on manganese reduction in the rhizosphere and manganese concentration in maize (Zea mays L.), New Phytol. 117 (1991) 649-655.

[21] Landis T.D., Tinus R.W., McDonald S.E., Barnett J.P., The Container Tree Nursery Manual, Vol. 1, Nursery planning, development and management, Agric. Handbk. 674, Washington D.C., U.S. Dept. Agric. For. Serv., 1995.

[22] Marschner H., Mineral nutrition in higher plants, Academic Press INC, San Diego, 1986.

[23] Marx D.H., Ectomycorrhizal fungus inoculation: a tool for improving forestation practices, in: Mikola P. (Ed.), Tropical mycorrhiza research,Oxford Univ Press, New York, 1980, pp. 13-71.

[24] Marx D.H., Ruehle J.L., Cordell C.E., Methods for studying nursery and field responses of tree to specific ectomycorrhiza, Methods of Microbiology 23 (1991) 382-411.

[25] Montoya J.M., El pino piñonero, Agroguias Mundi-Prensa, Madrid, Spain, 1989.

[26] Mousain D., Argillier C., Sardin T., Brahic P., Mauré L., Plassard C., Intérêt de la mycorhization contrôlée des espèces forestières en pépinière pour le reboisement des zones difficiles, Revue d'Analyse Spatiale Quantitative et Appliquée 32 (1992) 127-134.

[27] Mousain D., Plassard C., Argillier C., Sardin T., Leprince F., El Karkouri K., Arvieu J.C., Cleyet-Marel J.C., Stratégie d'amélioration de la qualité des plants forestiers et des reboisements méditerranéens par utilisation de la mycorhization contrôlée en pépinière, Acta Bot. Gall. 141 (1994) 571-580.

[28] Parladé J., Pera J., Alvarez I.F., Inoculation of containerized Pseudotsuga menziesii and Pinus pinaster seedlings with spores of five species of ectomycorrhizal fungi, Mycorrhiza 6 (1996) 237-245.

[29] Parladé J., Luque J., Pera J., Rincón A., Field performance of Pinus pinea and Pinus halepensis seedlings inoculated with Rhizopogon spp. and out-planted in formerly arable land, Ann. For. Sci. 61 (2004) 507-514.

[30] Posta K., Marschner H., Römheld V., Manganese reduction in the rhizosphere of mycorrhizal and non mycorrhizal maize, Mycorrhiza 5 (1994) 119-124.

[31] Rincón A., Álvarez I.F., Pera J., Ectomycorrhizal fungi of Pinus pinea L. in northeastern Spain, Mycorrhiza 8 (1999) 271-276.

[32] Rincón A., Álvarez I.F., Pera J., Inoculation of containerized Pinus pinea L. seedlings with seven ectomycorrhizal fungi, Mycorrhiza 11 (2001) 265-271.

[33] Sánchez-Monedero M.A., Roig A., Cegarra J., Bernal M.P., Noguera P., Abad M., Anton A., Composts as media constituents for vegetable transplant production, Compost Sci. Util. 12 (2004) 161-168.

[34] Smith S.E., Read D.J., Mycorrhizal Symbiosis, Academic Press, Cambridge, 1997.

[35] Stenström E., Ek M., Field growth of Pinus sylvestris following nursery inoculation with mycorrhizal fungi, Can. J. For. Res. 20 (1990) 914-918.

[36] Van den Driessche R., Soil fertility in forest nurseries, in: Duryla M., Landis T.D. (Eds.), Forest Nursery Manual. Production of bareroot seedlings, Martinus Nijhoff/W. Junk Publ., The Hague, 1984, pp. 63-74.

[37] Williams S., Official methods of analysis of the Association of Official Analytic Chemists, Sidney W. (Ed.), AOAC, Inc. Arlington VA, 1984. 